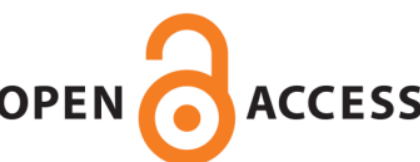

UWS Academic Portal

\title{
A Marxist analysis of American gun culture
}

James, Kieran; McKenzie, Jodi

Published in:

International Journal of Critical Accounting

DOI:

10.1504/IJCA.2018.098269

Published: 08/03/2019

Document Version

Peer reviewed version

Link to publication on the UWS Academic Portal

Citation for published version (APA):

James, K., \& McKenzie, J. (2019). A Marxist analysis of American gun culture. International Journal of Critical Accounting, 10(6), 491-518. https://doi.org/10.1504/IJCA.2018.098269

\section{General rights}

Copyright and moral rights for the publications made accessible in the UWS Academic Portal are retained by the authors and/or other copyright owners and it is a condition of accessing publications that users recognise and abide by the legal requirements associated with these rights.

Take down policy

If you believe that this document breaches copyright please contact pure@uws.ac.uk providing details, and we will remove access to the work immediately and investigate your claim. 
This is a pre-copyedited, author-produced version of an article accepted for publication in International Journal of Critical Accounting following peer review. The version of record James, K., \& McKenzie, J. (2019). A Marxist analysis of American gun culture. International Journal of Critical Accounting, 10(6) is available online at: https://doi.org/10.1504/IJCA.2018.098269. 


\title{
A Marxist Analysis of American Gun Culture
}

\author{
By Kieran James* \\ University of the West of Scotland and University of Fiji \\ Kieran.James@uws.ac.uk and Kieran.james99@yahoo.co.uk
}

\author{
Jodi McKenzie \\ University of the West of Scotland \\ Jodi.kane@hotmail.co.uk
}

${ }^{*}$ Corresponding author Kieran James

School of Business and Enterprise

University of the West of Scotland

Paisley campus

High Street

Paisley PA1 2BE

Renfrewshire

SCOTLAND.

Tel: +44 (0)141 8483350

E-mail Kieran.James@uws.ac.uk and Kieran.james99@yahoo.co.uk 


\section{Biographical notes:}

Dr. Kieran James is a Senior Lecturer in Accounting in the School of Business and Enterprise at the University of the West of Scotland. He was formerly Accounting Professor at the University of Fiji. He researches in industrial relations, Marxism, popular music, and sports history. He has published scholarly articles in Critical Perspectives on Accounting, International Journal of Critical Accounting, International Journal of Sport Management \& Marketing, Musicology Australia, and Journal of Popular Music Studies.

Ms. Jodi McKenzie graduated with first-class Honours in Accounting from the University of the West of Scotland's Hamilton campus in July 2018. This article is a shortened and revised version of her Honours dissertation which was submitted to the University for grading in March 2018. 


\title{
A Marxist Analysis of American Gun Culture
}

\begin{abstract}
This study was carried out in order to gain insights into the attitudes and opinions of American citizens regarding gun culture in their country. In particular, the research aimed to identify what they perceived to be the main causes and influences upon gun culture; and what they believed were possible solutions to the gun culture. A survey was distributed to American citizens on the gun culture topic and it was completed by 57 respondents. The survey results show a variety of opinions with those of gun owners and non-gun owners contrasting. The gun owners' attitudes were in line with the beliefs and political views of the National Rifle Association; whereas the non-gun owners favoured more gun control laws to be passed in the future. The Marxist perspectives of Alienation Theory and Conflict Theory help us to understand better the American gun culture within the context of American capitalist society.
\end{abstract}

Keywords: Alienation; Capitalism; Conflict Theory; Gun culture; Marxism; Strain Theory. 


\section{A Marxist Analysis of American Gun Culture}

\section{Introduction}

\subsection{General Introduction}

In October 2016, a 14-year-old boy opened fire upon a school playground in South Carolina. The victim was a six-year-old boy named Jacob Hall. Jacobs’s friend, Ava Olsen, who suffers from Post-Traumatic Stress Disorder (PTSD) and is now home-schooled because of the incident, recently wrote a personal letter to President Trump asking what he is doing to "keep kids safe”. She received a vague reply in which President Trump expressed his sadness regarding her loss along with a promise that he would continue to focus on protecting Americans and improving safety (Pill, 2018). Since his reply, sent on 19 December 2017, 40 more children have died at the hands of gun violence, some were accidentally killed, some were murdered; all equally tragic and all preventable (Gun Violence Archive, n/d).

More people are killed by guns in a typical week in the U.S.A. than in all of Western Europe in a year. Love for guns pours outwardly through TV and movie screens daily whilst the media enforces the rule that guns are the solution to the violence already occurring. In a country where it is normal for schools to have metal detectors and the roots of gun culture are so deeply ingrained within the average citizen's psyche, will there ever be an end to the violence that tears the country and its citizens apart (Bellesiles, 1996)?

\section{Insert Figure 1 about here}

\subsection{American Gun Culture: A Brief History}

"A well-regulated Militia, being necessary to the security of a free State, the right of the people to keep and bear Arms, shall not be infringed" (2nd Amendment to the United States Constitution (U.S. Senate, $\mathrm{n} / \mathrm{d})$.

Americans have an exceptional and unique relationship to guns, starting with the militias of the revolution. History lies at the centre of the gun debate within the U.S.A. and the original meaning of the second amendment is controversial and often argued (Haag, 2016).

Adopted on 15 December 1791, the second amendment to the United States Constitution grants individuals the right to bear arms. Partisans of the gun debate argue that individuals have the right to carry a gun in the name of self-defence, recreation and, if 
necessary, to take up arms against the government (Cornell, 2006). However, Cornell (2006) believes that the true original meaning was not self-defence but a civic right to guarantee that each citizen was able to fulfil his legal obligation to participate in the well-regulated militia.

Prior to the American Revolution, the U.S.A. had neither the budget nor the manpower to maintain an army; therefore citizens protected themselves against armies and Native Americans by forming militias in which service was mandatory for all men. Cornell (2006) believes the second amendment is aimed at protecting these militias against the danger of being disarmed by the government and nothing more. Citizens were required to arm themselves at their own expense to protect their community and state, and eventually, nation. The government kept tabs on who owned what weapons at this time which Cornell (2006) describes as the (acceptable in his view) middle-ground between anarchy and tyranny.

The United States strived to have every man in the country armed; however, throughout the 17th and 18th centuries, the U.S.A. was reliant upon Europe for its arms and no effort was made to produce guns within the country. In 1808, Congress voted for a large proportion of the federal budget to be "for arming and equipping the whole body of militia of the United States” (Bellesiles, 1996). Even with this budget, the government's goal of arming America was not realized until the end of the Civil War in 1865 when the army allowed Union soldiers to take their firearms home with them.

Gun production within the U.S.A. escalated in the 1840s and 1850s when a series of gun manufacturers began operations, among them Colt, Remington, and Smith \& Wesson. The federal government provided the capital for production, patent protection, and technological expertise (Newport, 2016). Even at this time guns were viewed as an unexceptional object of commerce with no pangs of conscience attached to them (Haag, 2016). With this increased production came a gradual increase in interest in guns amongst American citizens. At this time only white male Protestant property owners were permitted to own guns. Hunting also became more popular during this time as an enterprise for would be gentlemen. Gun ownership within this social circle granted an instant status sought after by many and, seemingly overnight, the urban middle-class male became desperate to own one (Bellesiles, 1996).

The Colt revolver appealed to these "gentlemen" as they were relatively inexpensive; fired several rounds quickly; and were easy to conceal. The Colt revolvers offered no other function than self-defence and were clearly intended for personal use (Newport, 2016). The increased availability of guns and the victory in the Civil War led to a better-armed militia which attracted those who valued guns and demonstrated a disturbing willingness for a 
military lifestyle (Bellesiles, 1996). The initial consequence was, of course, an increased murder rate. In 1849, a shooting at Astor Place, New York, saw the militia open fire against and kill 25 civilians. This incident is now considered to be the first mass shooting of innocents in the history of the U.S.A. However, the fact that anyone can own a gun in itself does not create a gun culture. The National Rifle Association's (NRA) formation in 1871 also significantly contributed to the current situation of American gun culture. Gun advertising by the NRA, after its formation, focused on showing guns as a means of preserving the nation's freedom and providing security for one's family and from war, thus implying that firearms were necessary for social order and for control (Cornell, 2006).

The NRA was formed the same year the Ku Klux Klan was declared illegal and one of the first gun laws passed was to ban African-Americans from owning one (Ellis and Hicken, 2014). The bulk of the NRA's capital comes from donors, mostly firearm companies including Berretta, Midway USA, Smith and Wesson, and Strum Ruger (Follman, 2016). Their profits are instinctually linked to the success of the gun industry. In 2016 it was estimated that donations from gun companies totalled \$20-52.6 million and approximately $\$ 20.9$ million was earned from selling advertisements. Strum Ruger donates $\$ 1.00$ to the NRA for every gun sold amounting to millions each year and Taurus buys a NRA membership for anyone who buys one of their guns (Ellis and Hicken, 2014).

The money donated to the NRA is used for lobbying purposes to keep and pass more laws regulating gun controls and, over the last 40 years, the NRA has transformed from a largely non-political group into one of the most powerful organizations in Washington DC (Beer, 2017). Its abilities to successfully lobby and fund politicians are matched by few other contemporary American organizations (Younge, 2017).

The Civil War, the second amendment, and the efforts of the NRA combined helped bring guns into the home, making them a part of the domesticated environment and, to this day, an unquestioned extra member of the American family (Bellesiles, 1996).

\subsection{Karl Marx}

During Marx's lifetime his works addressed many political and social issues; however, his most influential works are arguably The Communist Manifesto, published in 1848 with his collaborator Friedrich Engels, and Das Kapital (Volume 1) published in 1867. Das Kapital laid out Marx’s vision of capitalism and its inevitable tendency towards self-destruction. The capitalist system outlined is prevalent in society today and the world is clearly now as Marx 
saw it, a constant struggle between the bourgeoisie (the ruling-class) and the proletariat (the working-class), with huge forms of exploitation occurring across society (Amies, 2008).

Marx's contribution to the understanding of modern society has been vast and his analysis of class structure and class conflict has had a major impact upon history and human culture; the influences remain strong 130 years after his death (Woods, 2013).

\subsection{Aims and Objectives}

This article aims to identify the political and social issues surrounding gun culture in America today whilst applying the theories of Marx. The article examines how Marx's understanding of capitalism is relevant to this chosen research topic as well as applying both Conflict Theory and Social Alienation Theory to the current climate of gun culture. A survey was submitted to American citizens to analyse their opinions and attitudes towards gun culture.

The present article aims to answer the following research questions:

(a) What do Americans perceive to be the main causes and major influences upon the gun culture?

(b) What do Americans believe are the possible solutions for the gun culture?

The remainder of the article is structured as follows: Section 2 provides background information; Section 3 presents theoretical frameworks; Section 4 describes research method; Section 5 presents the results of a survey which assesses American citizens' opinions and attitudes towards gun control; while Section 6 concludes.

\section{Background}

\subsection{Causes and Influences of Gun Culture in America}

America has a unique relationship with guns and this exceptional relationship is the foundation of American gun culture (Haag, 2016). The industry has grown five percent annually since 2007 (Plummer, 2012) but the question remains: How has America got to the stage where so many people own, carry, and use guns despite the overwhelming evidence that more guns on the street equals more gun violence, accidental deaths, suicides, and murders (Ramsey, 2017)? The question is of course unanswerable and the gun culture is aided by a powerful gun industry; political partisanship; and the hundreds of millions of guns which are already in the hands of American civilians (McCarthy, 2017). 
America has the most guns per 100 residents in the world, followed, secondly, by Serbia and, thirdly, by Yemen, a tribal nation with no history of a strong central government. America has 112.6 guns per 100 residents meaning that there is more than one gun for every American citizen. Even Russia, which the U.S. media and politicians like to cite as being lawless, has fewer guns per head of population than these three leading countries.

\section{Insert Figure 2 about here}

It has been theorized that the gun culture and violence is due to the underlying legacies and problems which are rife in the United States.

\subsection{The American Military Presence}

The U.S.A. has the largest military force in the world and an annual defence budget of \$598.5 billion. It is a military force like no other, larger than the U.K., China, Russia, India, France and German military combined (Giroux, 2016). The government will go to great lengths to stop terrorism, locking down cities and responding with extreme violence and vigour but will not pass gun control bills when the chilling truth is that toddlers kill more people annually than terrorists do (West, 2016). The Children's Defence Fund responded to this by asking:

\footnotetext{
"Where is our anti-war movement here at home? Why does a nation with the largest military budget in the world refuse to protect its children from relentless gun violence and terrorism at home? No external enemy ever killed thousands of children in their neighbourhood's streets year in year out."
}

Pavey (2017) also states that America has banned Kinder Eggs and Dodgeball as they are believed to be dangerous for children, yet Congress seem reluctant to even have a conversation about protecting children by introducing gun control measures.

The military presence is said to have played a role in the Columbine High School shooting of 1999. Not only was shooter Eric Harris's father a pilot in the Air Force, Harris and his family also lived in the town of Oscoda where Lockheed Martin, the largest weapon manufacturer in the country, employs over 5,000 within the local community. Aspects of capitalism are also at play here as the company has the same hold over Oscoda as General Motors once had over Flint, Michigan. Twenty percent of bombs dropped by America in the Iraq war took off from the military base in Oscoda with Harris's father even flying some of 
the jets. Langman (n/d) asks how is it possible for children to distinguish between the notions of right and wrong when they are surrounded by war and violence in their everyday lives and led by a hypocritical government. Is it ok for 500,000 Iraqi children to die at the hands of America in the name of war? But not ok for American children to be killed on home soil?

Jiobu and Curry (2001) also believe that a lack of confidence in government is a contributor to the cause of gun culture. They found that those who mistrust the government are more likely to own a gun; this finding is in contrast to Miller and Borreli (1991) who found that confidence in government does not affect gun ownership. Jiobu and Curry (2001) suggest that guns represent an individual's feelings of empowerment against forces which they deem to be threatening. For some this may be a powerful government. Kleck (1996) suggests that some people lose confidence in social institutions and so arm themselves to deal with their insecurities.

\subsection{How Mass Shootings affect the Gun Culture}

The American public are outraged after mass shootings even though they only account for a small proportion of gun deaths annually (McCarthy, 2017). Mass shootings generally lead to gun control debates and perhaps the passing of some bills. The NRA works hard to silence these proceedings by rallying gun owners and placing the blame elsewhere (Lopez, 2017).

Ironically, mass shootings usually mean big business for the gun industry. Fear is ultimately good for the businesses' bottom lines with sales being driven by anxiety. In some cases, this anxiety is due to feeling unsafe and in other cases it is due to fear that the government will push through laws restricting the buying of guns. After 9/11, background checks (considered a good indication of gun sales) shot up twenty-two percent from August 2001 to September 2001. In late 2012, after the Sandy Hook Elementary shooting and Aurora cinema shooting, background checks rose by eighty-two percent which was an all-time record. Manufacturers Smith and Wesson saw their net sales up forty-three percent and Strum Ruger sales also rose to \$491.8 million in 2012 (from \$328.8 million in 2011) (Hill, 2016).

The weekend after the Sandy Hook shooting saw 120,000 guns being sold. The Bushmaster AR-15 (eerily similar to the gun used by Adam Lanza in the shooting) sold faster than it could be produced (Plummer, 2012). This so called "Sandy Hook Surge" corresponded with an increase in accidental gun deaths with 80 deaths in the five months following, 20 of which were of children (Pinsker, 2017). A similar situation occurred after the Las Vegas shooting of 2017. Shares in gun manufacturers rose just hours after the tragic 
event with Strum Ruger shares up four percent; Smith and Wesson up three percent; and Winchester up six percent (Pinsker, 2017).

\subsection{NRA Influence and Marketing}

The NRA's biggest asset is its members who are very politically active and engaged with their cause. It has used advertising to change how Americans view the second amendment, from a historical militia-based perspective on guns to one which focuses upon individual rights to gun ownership in the here and now. The NRA's ads in the early-1980s were diverse, featuring ethnic minorities, women, men, children, and celebrities. Towards the end of the decade, their focus shifted to crime and fear-mongering with taglines such as: "Should you shoot a rapist before he cuts your throat” (Beer, 2017).

In 2013, after President Obama moved to ban automatic weapons; limit magazines to ten bullets; and enforce universal background checks, the NRA responded by publicly opposing the president. After the Sandy Hook Elementary shooting of 2012, it criticized Obama for using the secret service to protect his children, calling him an "elitist” and a "hypocrite” for opposing its plan to install armed guards in every school to prevent further tragedies of a similar nature (Beer, 2017).

The NRA is one of the most powerful lobbying groups in the country. A poll carried out in 2016 by Gallup found that fifty-eight percent of Americans are in favour of the NRA with only thirty-five percent having an unfavourable view (Swift, 2015). The poll also found that sixty-eight percent of Democrats believed the NRA to have too much influence over gun debates and reforms (Densley and Peterson, 2017).

In 2016, the NRA raised \$366 million - a record amount for the organization. In the same year, NRA spending surged \$100 million with the group allotting over \$30 million on the Donald Trump campaign alone (more than the organization spent on the 2008 and 2012 presidential elections combined) (Maguire, 2017). Trump was outspoken in his support for the NRA during his campaign, saying that he wanted to eliminate gun-free zones and that he believed that if more people were armed there would be fewer mass shootings. The president made an appearance at the NRA's annual meeting after he was elected and professed: "You came through for me, and I am going to come through for you.” Trump then revoked background checks for those with mental health issues, prohibiting social security administration from reporting anyone with these issues (Choma and Kroll, 2016). 
The existence of gun culture has also led to businesses outside of the industry using guns as a marketing tool. Michael Moore's ground-breaking documentary Bowling for Columbine (2002) tells the story of the Columbine shooting. The opening scene shows Moore opening an account with North Country Bank and receiving a free gun for doing so. This seemingly wild incentive is not uncommon in America. Bergeron's restaurant in Louisiana offer a ten percent discount to anyone carrying a gun, an offer which increased business by twenty-five percent. Jewellery by Harold in Iowa offered a free Remington 870 rifle with any diamond ring purchased over \$1,999 and Nations Trucks in Florida offer a free assault rifle with every truck bought. Unbelievably, there is even a business in Alabama, Holy Smoke Bullets, which will turn ashes into bullets for \$1,250 (Blumenfeld, 2016).

\section{Theoretical Frameworks}

\subsection{Introduction}

Firstly, the theories of Marx that are relevant to the research topic of American Gun Culture, namely Conflict Theory, Social Alienation Theory, and Marx's vision of capitalism, will be discussed before going on to provide examples of how these theories relate to the chosen topic.

\subsection{Conflict Theory}

Karl Marx is seen as the father of Conflict Theory. He believed that capitalist society (as well as previous modes of production) exists in a state of perpetual conflict due to competition for limited wealth, status, power, and resources. Conflict Theory is also used to analyse many social phenomena such as war, discrimination, and violence (Rummel, 2017).

Conflict Theory originated within the works of Marx who focused on the conflict between the bourgeoisie and the proletariat within capitalism as well as the implications of capitalism's rise. He believed that the unequal social order is maintained through coercion (as well as via ideology) with the proletariat accepting the environments determined by the more powerful bourgeoisie. He believed that, one day, the proletariat would revolt and demand changes in order to smooth the conflict between classes; however he theorized that, if these changes appeased the capitalist system, then conflict would never be eradicated. Socialism, according to Marx, is the only option for social stability (Crossman, 2017). 
Many theorists have built upon Marx’s Conflict Theory. The American C. Wright Mills in particular drew on Conflict Theory to describe the rise of a "power elite" comprised of the leading people in military, large economic organizations, and politics. Mills believed that America has a social system in which all the power and decision-making is in the hands of an elite group of people with similar background and outlooks. These people are upper-class; attend the same schools and Ivy League colleges; and join the same organizations and clubs. Mills stated that the masses of people in America are ruled by this elite group and that they are ill-informed and virtually powerless. They are economically dependent upon the elite's businesses or government and are politically exploited (Elwell, $\mathrm{n} / \mathrm{d}$ ).

Conflict Theory can be applied to many social divisions with the U.S.A. such as race, religion, class, gender, sexuality, culture; and indeed the gun debate itself (Crossman, 2017). Giroux (2016) believes that the number of mass shootings and gun violence in America is symbolic of a society which is living in permanent (unresolved) conflict.

Strain Theory, developed by the American Robert King Merton in 1938, is similar to Conflict Theory. Merton believes America has set unrealistic goals upon its citizens and puts pressures upon individuals to achieve the American Dream. He argues that society has encouraged deviance due to the pressure to conform to this ideology. ${ }^{1}$ The cultural system of the U.S.A. was built upon the idea of the American Dream and people were encouraged to pursue success which is these days largely measured by one's wealth and material possessions. Merton explains that this goal is simply unattainable for lower classes and,

\footnotetext{
${ }^{1}$ The reality is that there have always been two versions of the American Dream (Beach 2007: p. 151). The first version, based on the radical content in Jefferson's Declaration of Independence, emphasizes how one's hard work and entrepreneurial talent allows oneself to provide a better standard of life for oneself and one's descendants. This version argues that race, religion, ethnicity and political orientation (the hallmarks of social stratification back in the old countries) are not forces strong enough to prevent a person from attaining the success promised by the American Dream. However, Beach (2007, p. 151) argues that contradictions within American society (and even in Jefferson's own mind) right from the beginning meant that the seeds of a more conservative version of the American Dream (the "counter-ideal") were also contained within the same Declaration. Jefferson's notion of agrarian democracy assumed a world of exploitation of slave-labour and indentured servants by plantation owners, and his educational vision in reality extended only to propertied white males. Even his model University of Virginia was built by slave-labour and was whites-only until the early1970s (Beach, 2007, p. 151). Beach (2007, p. 151) comments that: "Meritocracy, the conservative notion of the American Dream, praised self-reliance, hard work, frugality, dutiful industry, success, and prosperity". By the nineteenth century this conservative version would push aside Jefferson's more radical American Dream and become "the binding ideology of the nation" (Beach, 2007, p. 151). The radical critique focuses on how this counter-ideal has always served ideological functions because one's actual ability to take advantage of opportunities is a function of pre-existing living and working conditions and related factors such as ethnicity, religion, race, gender, political orientation and location. In his brutally direct manner, which more politically correct and sophisticated authors would eschew, Gene Simmons of the heavy-rock band KISS (Simmons, 2006, p. 67) tells us that: "Not everyone can climb Mount Olympus; somebody's got to wrap fish". The ideological functions served by the American Dream concept are thus to ensure that people remain hard-working, lawabiding and ever-hopeful; and that they blame themselves or bad luck rather than the system when they fail to achieve their life-goals.
} 
therefore, crime is encouraged within these communities (Revise sociology, n/d). Baron (2006) states that America is a highly unequal and divided society which promotes goals only a minority can achieve. This correlates to how Marxists view capitalist society, as lack of equal opportunities for all lies at the heart of the capitalist system. Qui (2014) believes that Strain Theory may be a factor in ethnic communities and it explains why the main cause of death for young African-American males aged 15-34 is homicide by gun, with ninety-three percent having been shot by another man of the same race.

\subsection{Social Alienation Theory}

Marx's most important early writings on alienation can be found in The Economic and Philosophic Manuscripts of 1844. He largely focused upon how workers are, and hence feel, alienated under capitalism as they have no control over the means of production. They are objectively alienated from the act of producing; the products produced; their true-natures; and other workers (Darnall, 2011). Social alienation will be the focus of this study.

Sociologist Melvin Seeman took Marx’s theory further in his work The Meaning of Alienation published in 1959. He described social alienation as a sense of a lack of power over one's life; a lack of self-worth; and an absence of meaning. Seeman believed that economic instability, and the social upheaval that goes along with it, are major causes of social alienation (Arineri, 1968). Those people living in poverty are said to experience alienation more as they are unable to participate in society in a way that is considered normal. Those living at the lower rungs of the social hierarchy in terms of race and / or class are also more prone to suffer the effects of alienation (Crossman, 2017). However, Darnall (2011) believes that different social classes can experience their own forms of alienation.

Hong (2010) believes that social alienation played a major role in a 2000 school shooting in Flint, Michigan when six-year-old Dedrick Owens brought a gun to school and shot his classmate Kayla Rolland. Kayla was the youngest school shooting victim until the Sandy Hook Elementary shooting incident twelve years later. Hong (2010) is of the opinion that social alienation in inner-city communities leads to youth violence and crime. She believes that this is often due to violence within the neighbourhoods and the breakup of families which is rife within ethnic communities in America.

At the time of the shooting, Dedrick Owen's father was in jail for violating parole, in relation to his previous charge of possession and intent to sell cocaine. Dedrick's mother, Tamarla Owens, was at work on the day of the shooting under the government's Welfare to 
Work scheme. Each day she was forced to make an 80-mile round trip to work for 70 hours a week earning the minimum wage (Rosenblatt, 2000). Welfare to Work has come under fire for driving parents away from children and for forcing mothers to work for large corporations for wages unable to save them from poverty. It has been said that this welfare reform was basically a legal form of child neglect and deadly for low-income communities (Ferrara, 2014). This reinforces Darnall's (2011) argument that the root cause of alienation can be found within capitalism (with the state ultimately being a servant of capitalism). Tamarla was working two jobs and was still unable to afford rent. This led to the family being evicted a week before the shooting with Dedrick being sent to live with his uncle in a house that the Genesee County Sheriff later described as "living in hell”. It was here that Dedrick found a loaded gun which he took with him to school and fatally shot Kayla Rolland (Rosenblatt, 2000).

The dynamics of global capitalism have had a major impact upon Flint, Michigan. Flint was once a thriving community with the majority of residents having been employed by General Motors. When the company closed two of its plants and left town, jobs moved overseas, and Flint fell into a state of economic despair. The company once sustained the whole community and, when it left, this resulted in mass unemployment and poverty. Economic depression and social despair brought this once hopeful city to a state where shootings are now the main cause of death and eighty-seven percent of school pupils, like Dedrick Owens and Kayla Rolland, live below the poverty line (Felton, 2017).

Social alienation also plays a major role in the many mass shootings that plague America. The Federal Bureau of Investigation (FBI) defines a mass shooting as being four or more people killed by the same perpetrator with no cooling-off period in between killings (Nichols, 2017). Multiple studies have shown that many school shooting perpetrators show signs of mental health issues, suicidal ideation, and having been bullied by peers. A mass shooter profile usually presents a person isolated and detached from his or her community and who claims to be an outsider (Brent et al., 2013).

\subsection{Capitalism in America and how it affects Gun Culture}

Capitalism is a social system or mode of production that is prevalent in almost all countries of the world. Under the capitalist system the means of production are owned by a small minority of people (bourgeoisie). The motive for producing these goods and services is profit or the rate of return on capital. The majority of people, the working-class (proletariat), sell their labour-power to the capitalists, in return for a salary, in order to survive. Within capitalism it 
is obvious that the two main classes have divergent interests. These divergent interests give rise to competing political, religious, and ideological views as most people tend to prefer to hold views and practices consistent with their economic interests. As Ewell (2007) explains, citing Marx and Engels from The German Ideology of 1845-46: "The ideas of the ruling class are, in every age, the ruling ideas.”

A recent survey by F. Carson Mencken and Paul Froese surveyed 1,572 men across 48 U.S. states and found that legal gun owners in America are seventy-eight percent white and sixty-five percent male. Within this dynamic they found that those who had suffered some form of economic setback were significantly more attached to their guns. The conclusions drawn from their survey are that these white men are not living up to the expectations America has placed upon them and look to guns to replace lost masculinity; they do not feel as powerful or as economically successful as they believe that they should feel. By contrast, non-white male gun owners do not feel the same pressures as society has not placed the same expectations upon them.

Fraad and Wolff (2017) theorize that, when the global world market hit heartland America, this development encouraged companies to shift production overseas in the restless quest to find cheaper and cheaper labour sources. The capitalists in America stopped worrying about paying good wages and providing benefits. Previous to this, the average American white male was able to provide for his family solely with one wage. His wife was able to stay at home to raise the children, keep the house, and arrange the social calendar. White men lost their sense of power when developments within capitalism meant this was no longer the case. The dutiful wives are now required to work; child rearing and household chores have to be shared; and some white men feel emasculated. This in turn makes them vulnerable to advertisements for products endorsing power, namely, guns. Gun manufacturer Bushmaster even advertised using the tagline: “Consider your man card reissued”.

Disempowered people will often look to blame certain social groups; and politics in America focused this blame upon immigrants and minorities. However, capitalism was never blamed for ending the American Dream. Instead the media created even more conflict: immigrant versus native, men versus women, in turn generating a divided mass of people caught up in various struggles whilst the capitalists accumulated wealth and evaded criticism.

Fraad and Wolff (2017) see elements of modern capitalism in play in the deadliest mass shooting in America's history, the Las Vegas shooting of 1 October 2017. The shooter, Stephen Paddock, had amassed a personal fortune but had no on-going job where he could be social. He made money via real estate and then spent his time alone gambling in casinos. He 
and his live-in girlfriend were said to not socialize with anyone. Paddock was alienated from his family; his last known contact with family was his brother three years previous to the shooting. He had had no contact with other family members for in excess of 20 years. Fraad and Wolff (2017) believe that the lack of stability associated with having no daily job leads to loneliness and social alienation and possibly mental instability which could be considered reasons for Mr. Paddock committing this heinous crime (Barnes, 2018).

\section{4. $\quad$ Research Method}

\subsection{Introduction}

The purpose of this section is to describe the research methods which were used in this study, as well as to explain the choices made. Firstly, the research questions are restated. A later sub-section will justify the research approach chosen.

\subsection{Research Questions}

This article aims to satisfactorily answer the following research questions:

(a) What do Americans perceive to be the main causes and major influences upon the gun culture?

(b) What do Americans believe are the possible solutions for the gun culture?

\subsection{Research Approach}

A quantitative research method was used to collect primary data. The quantitative research undertaken was in the form of a survey which aimed to identify American citizens' attitudes and opinions about their country's gun culture.

\subsection{Research Limitations}

The questionnaire used in this research has some limitations. Firstly, the survey was designed early in the research process; however, due to approval from our University's Ethical Review Committee taking much longer than anticipated, the survey was only in circulation for two weeks and therefore did not receive as many responses as the researchers anticipated. This means that the sample size is fairly small, and care must be taken in generalizing the findings to the population. Secondly, the survey was designed to gather the attitudes and opinions of American citizens regarding gun culture in their country. As the researchers are based in 
Scotland, the survey was circulated on Twitter with the stipulation that only Americans complete it. However, the researchers have no way of knowing that every respondent was indeed an American citizen. Lastly, the survey was distributed on Twitter just one week after the Stoneman Douglas High School shooting in Parkland, Florida. The closeness to this incident may have generated a more emotional response in some respondents than what might have been the case had the survey been distributed at a different time.

\subsection{American Gun Culture Survey}

The survey was made through the data collecting software, Qualtrics. As mentioned above, the survey was distributed on Twitter via one of the researcher's personal Twitter account. This researcher deliberately did not ask for respondents on any Twitter pages or threads that were previously related to, or discussing, guns in any form. This was to ensure that the respondents would be diverse and not all share the same pro- or anti-gun opinion.

The survey consisted of sixteen (16) questions and there were fifty-seven (57) respondents. It was designed to gain an understanding of what Americans perceive to be the causes and influences of gun culture, as well as what factors they believe will affect the future of gun culture. Questions 1 to 3 were aimed at identifying the demographics of the respondent population. Many of the remaining questions were answered by using the Likert Scale developed by American social scientist Rensis Likert in 1932. This allows questions to be answered with a greater degree of nuance than a simple yes or no answer. The scale offers a wide range of answer options ranging from "extremely likely” to "not likely at all” with an option to remain neutral. Using the Likert Scale allowed the researchers to design questions that the respondents would not feel too overwhelmed with, which could have led to frustration and possible interference with the data (Cherry, 2017).

The survey included one ranking question which asked the respondents to compare choices by placing them in a ranking order. Open-ended questions were also utilized as the survey was intended to canvas attitudes and opinions; these types of questions allowed the respondents to answer exactly how they wanted to and allowed the researchers to investigate these responses further.

The survey was distributed via Twitter to Twitter accounts and threads that the researchers believed would include American citizens. The survey link was provided with the stipulation that only American citizens respond. The respondents were also told, at this stage, that their answers would be completely anonymous; this was then restated at the beginning of 
the survey. It was important to the researchers that the respondents were fully aware of their anonymity as this topic is a sensitive issue for some individuals and the researchers wanted to ensure that social desirability (the urge for individuals to paint themselves in a more positive light) would not unduly influence the responses (Fisher, 1993).

Before commencing the survey, the respondents were greeted with the following message: "You are being invited to participate in a research study on attitudes and opinions of American gun culture. This will not take longer than five minutes to complete, is completely anonymous and you are free to opt out at any time”. Respondents then had to select “I agree to participate” before they could begin answering the survey questions.

\section{Results}

\subsection{Introduction}

This section examines the results of our survey. The researchers determined that the best method of analysis would be to compare the attitudes of gun owners and non-gun owners, as well as the attitudes of males and females. This method was chosen as the researchers felt that this mode of analysis would highlight the diverse views on the issue more clearly.

\subsection{Survey Results - Demographic Questions}

Question 1 was a demographic question which determined the respondent's age. The most common age for male respondents was 25-34 with 9 of the respondents selecting this bracket. This differs from female respondents as ages 25-34 was the least common bracket with only 4 selecting this. The least common age bracket overall was age 65+ with only 1 male respondent selecting this and 0 females.

The female respondents were more evenly distributed among age groups with the most common age bracket being 16-24 with 14 of the respondents falling into this bracket.

Overall, age bracket 16-24 had 18 respondents in total; age bracket 25-34 had 13; age bracket 35-44 was slightly less common with only 7 respondents; age bracket 45-54 had 12 respondents; age bracket 55-64 had only 6; and age bracket $65+$ had only 1 . These results show that most age brackets are fairly evenly represented with the exception of age 65+. A questionnaire given out in hard-copy in a real-world location, such as a shopping mall or library (excluding university libraries), would probably have had a larger proportion of middle-aged and elderly respondents. This dynamic could have influenced our overall results; 
so it is better to label our results "online attitudes towards gun culture" rather than "attitudes towards gun culture”.

Question 2 was another demographic question, this time asking the respondent to specify gender. Upon reflection, the researchers realize that this question would have made more sense being question 1; however, by the time the researchers had decided this, the survey had already been distributed.

The results show that more females than males participated in the survey with 23 of the respondents identifying as male and 34 as female. No respondents selected the "prefer not to say” option provided. Overall, there were 57 respondents.

Question 3 was the last demographic question and it asked for the respondent's employment status. "Employed full-time" was the most frequently selected status with 33 of the overall respondents selecting this option. Only 3 people selected "employed part-time" and 3 also selected "self-employed". Eleven (11) respondents were "students" and 7 respondents chose not to disclose their status.

\subsection{Survey Results - Other Questions}

Question 4 simply asked respondents whether they owned a gun. This was a closed question with only yes or no options provided as answers. It was deliberately set up that way by the researchers so that we could compare the attitudes of gun owners and non-gun owners. The difference between genders is evident here and shows that males are more likely to be gun owners with a staggering 17 of the 23 respondents owning a gun; this works out to $74 \%$ of the overall male respondents. This is in stark contrast to the female respondents as 29 of the 34 respondents are not gun owners meaning that only 15\% of female respondents own a firearm. This is in agreement with Mencken and Froese (2017) who found that $78 \%$ of American gun owners are male.

\subsubsection{Male Gun Owners’ Responses}

Firstly, the male gun owners' responses will be analysed. Of the 17 gun owners who responded, over 82\% were middle-aged and employed full time. This agrees with what is considered to be the profile of a typical American gun owner, i.e. male, middle-aged, white, and semi well off. The spokesman for American Death Metal band Deicide, Glen Benton, famously shot a squirrel in his backyard during a live band interview with $N M E$ magazine. This was perceived to represent a typical American or Floridian attitude to life; there was a 
bomb explosion at a Deicide concert in Stockholm, Sweden, and this was widely attributable to be the work of animal activists who despised Benton.

Of the $74 \%$ of males who are gun owners, $59 \%$ cited "for my protection" as one of their reasons for ownership with the most commonly selected reason being "it is my right as an American”. These results are presented in Figure 3.

\section{Insert Figure 3 about here}

We can see the second amendment in play here, also the gun industry and NRA marketing aimed at men seems to play a crucial role. The majority of these men believe that they need to own a gun in order to protect themselves, or perhaps their family. The study by Jiobu and Curry (2001), which suggested that guns represent an individual's feelings of empowerment against forces that they deem threatening, appears to be especially relevant here. Perhaps these men feel disempowered in some way and so arm themselves to regain self-confidence. This reasoning is supported when we look at the answers given by males in question 8 of our survey, which asked the respondents to rank the following factors in order of their perceived influence upon American gun culture: (a) the ease to own a gun legally; (b) the influence of TV, films and other media; (c) family influences and/or instability; (d) the large American military presence; (e) NRA influence; and (f) lack of economic opportunities.

No male gun owner put "NRA influence" as one of his top three choices. Although this result might be interpreted as suggesting that the NRA has no perceived real influence upon gun culture, it might instead suggest that the NRA influence either operates at the subconscious level, by legitimating aspects of a culture, or is perceived as benign or simply informative rather than having any independent causal effects.

The most popular option was "lack of economic opportunities” which can be linked back to Marx's understanding of capitalism and how the constant changes and adjustments within this mode of production in America have threatened and emasculated males to such an extent that they look to replace this lost masculinity through gun ownership. This result is largely in agreement with Mencken and Froese (2017) who found that males who had

suffered some form of economic setback were more attached to their guns and that white males in America who cannot live up to the expectations set upon them are more likely to own a gun. Elements of Merton's Strain Theory are also evident in this answer as these men may not be living up to the American Dream which Merton believes then inspires deviant behaviour. 
"Family influences and/or instability" was chosen by $47 \%$ of respondents in their top three choices which again can be linked to capitalism and alienation. Perhaps these men's families have been affected by issues such as job losses or family break-ups. Perhaps they feel a sense of a lack of power. It could also be the case that these respondents live or grew up in under-privileged neighbourhoods where individuals are more prone to experience alienation. However, further questioning would need to be carried out in order to determine whether this was the case in the majority of instances.

Fifty-three percent (53\%) put "influence of TV, films and other media" in their top three choices suggesting that they believe that the consumption of violence may lead to violent behaviour. Once again, we can see the NRA influence upon gun owners. The NRA is very outspoken in proclaiming that violent media causes shootings, as opposed to gun ownership and access, despite Lemieux’s (2014) research showing that "gun ownership and access” is in fact the best predictor of death by firearms. Only $29 \%$ of male gun owners in our survey chose "the ease to own a gun legally" in their top three choices making this the least popular choice, ranking after "military presence" at 35\%. This result may indicate an unwillingness to accept a cause for gun culture and shootings which seems almost selfevidently valid.

Of the male gun owner respondents, 11 of the 17 have either been shot themselves or know someone who has been shot. There were 2 respondents who left further comments in this section, one simply stated "patient" suggesting that this respondent works in a medical capacity and knows of a patient who was shot. The other stated: "I know a fair few people who have been shot. Some fatally. All within my old neighbourhood when I was a young boy.” We can read between the lines here and assume that the neighbourhood this respondent grew up in was a tough one or perhaps even an ethnic community where gun crime rates are higher. Aspects of social alienation can be attributed to these low-income communities as demonstrated in earlier sections of this article. It is theorized that social alienation within these communities leads to violence and crime.

Interestingly, some responses do tally with what people would perceive to be a "gun owning mentality”. For instance, when asked if they believe that stricter gun laws should be passed, 35\% answered "definitely yes", 30\% remained "neutral”; and 35\% chose either “definitely not” or "probably not”. However, in contrast, when the respondents were asked if they believe guns to be a social or political issue, 35\% opted for the "I don't believe guns are an issue” option. Also, when asked if they believe guns should be banned as many as $76 \%$ 
selected "definitely not" or "probably not". These last two responses are in line with the researchers' prior expectations with respect to gun owners' probable responses.

Question 12 was similar to question 8 and was designed to gain a further understanding of the respondents' attitudes surrounding some of the most highly debated issues regarding gun culture. Respondents were asked to select all statements that they agreed with from the following options: (a) the mentally ill should be prevented from buying guns; (b) background checks on purchases at gun shows should be performed; (c) federal database tracking gun sales should be enforced; (d) assault weapons and high capacity magazines should be banned; (e) conceal-and-carry should be allowed in more places; (f) teachers should carry guns in schools and colleges; (g) gun control laws should focus on the secondary market; and (h) guns should be outright banned.

The male gun owners' responses are presented in Figure 4.

\section{Insert Figure 4 about here}

The fact that $76 \%$ believe that the mentally ill should be prevented from buying guns again shows the NRA's influence upon the gun owning population. The NRA routinely raises the mental health issue after major shootings in America, despite a study by the ECA (1990) which concluded that the mentally ill are in fact less violent than others; and that issues such as drugs, poverty, family influences, and alcohol misuse are much more likely to influence potential shooters.

Seventy-six percent (76\%) also agreed that background checks should be performed at gun shows, which again is another proposition put forward by the NRA whenever talks regarding changes to gun controls arise. Forty-one percent (41\%) called for conceal-and-carry laws to be allowed in more places suggesting that these respondents would like the law to allow the possession of firearms at all times. These men may feel that conceal-and-carry may deter violent criminals as they could potentially be intercepted by an armed member of the public, however, the Mother Jones analysis of 62 mass shootings showed that not once has this ever been the case. Also, 23\% agreed that teachers should be armed in schools, a debate which is currently rife in America at the time of writing, with even President Trump calling for this change.

Somewhat strangely, $11 \%$ of respondents chose the option to ban guns completely in this question. This could simply have been a mistake on behalf of the respondents as it is a rather strange statement for a gun owner to be agreeing with. One of these respondents left 
the following further comment at the end of the survey: "Although the subject of guns is socio-political, it is unfairly debated as...solely [a] political issue which will never lead to a suitable resolution due to political allegiances ...[and] [un]dying interests.” The comment suggests that the respondent believes guns to be a social issue but it is only ever debated as political issue; therefore, a resolution will never be found. His comment also mentions "due to political allegiances" which the researchers presume to be a veiled reference to the NRA and those politicians who support it.

The NRA's influence is evident in every answer given by the male gun owners as their attitudes are broadly in agreement with NRA policies and priorities. An interesting question to add to further studies would be to determine if the gun owners were NRA members or not which would allow the researchers to further analyse results and observe any differences in responses between NRA members and non-members.

\subsubsection{Female Gun Owners’ Responses}

Of the female respondents, only $15 \%$ were gun owners; the most frequently selected age bracket for female gun owners was age 16-24 and 60\% were "employed full time”.

In agreement with the male respondents, the females cited "for protection" as their main reason for ownership with $80 \%$ selecting this option. The second most frequently selected option was "sports and or/hunting" with $40 \%$. Only $20 \%$ selected "it is my right as an American”. None of the respondents had been a victim of a gun crime; however, 2 respondents knew someone who had.

The females' answers to question 8 are shown here.

\section{Insert Figure 5 about here}

We observe that zero respondents selected "NRA influence" which is in agreement with the male gun owners' responses. It is more than probable that this organization indeed has a significant influence upon gun owners but, as mentioned earlier, this is either at the subconscious level or owners do not want to acknowledge this influence as it might suggest that they cannot "think for themselves" and are "easily influenced". Females disagreed with the males about what they perceived to be the major influences upon gun culture as the most frequently selected option was the "ease to legally own a gun". However, we can also see that most females agreed with the belief that violent forms of media impact upon society. The 
options which implicate capitalism, namely "family influences" and "lack of economic opportunities”, are not popular selections for the female owners. This agrees with Mencken and Froese (2017) and Fox and DeLateur (2014) who argue that capitalism and the expectations imposed by American Dream ideology mostly affect the conscious thought processes of males.

Eighty percent (80\%) of females agreed that stricter gun laws should be passed, and $40 \%$ believed that guns should be banned altogether which is not in agreement with popular perceptions about gun owners' attitudes. Again, in question 12, 40\% also selected the option to ban guns. The researchers are unable to determine why gun owners would call for guns to banned; further questioning of these respondents would need to be carried out in order to clarify the reasons for these choices. Perhaps they were referring to an "ideal world" scenario and they carry guns in practice because the world is obviously imperfect and dangerous.

One hundred percent (100\%) of the female respondents believed that the mentally ill should be prevented from carrying guns; however, when asked later in the survey if they believed that mental health plays a role in mass shootings, only $60 \%$ of respondents believed this to be true. We observe that the females also called for teachers to carry weapons and for conceal-and-carry laws to be expanded to more places. Again, this is in agreement with the NRA's policies on these matters. The result about school-teachers is slightly surprising, as it appears here that the females put teachers in the roles of saviour and protector of children rather than as a risk in and of themselves; they do not perceive that teachers carrying guns will inspire or encourage violence indirectly through knock-on effects.

The results of question 12 can be seen here.

\section{Insert Figure 6 about here}

These results are in agreement with prior expectations. The attitudes of gun owners, whether male or female, were expected to be largely the same. Two (2) female respondents chose to leave further comments. One respondent stated: "I am the wife of a police officer; a legal gun owner and even before my husband was an officer we used to shoot for hunting and hobby. I believe mental illness including bullying has a lot to do with gun violence also with the ease of obtaining a gun.” This respondent was very clear regarding her perceptions about the key factors influencing gun culture, namely, mental illness and the ease to obtain a gun.

Another respondent stated the following: 
"My father raised me and my siblings and always ensured we knew our rights as Americans to own guns for protection of ourselves and our families. This is something I now teach my own child. Guns are not an issue within my country, mental health is the issue. Every shooter at schools has a mental health issue.”

NRA and Republican values are evident here as this respondent appears to feel strongly regarding the second amendment and believes mental health to be the issue, not guns.

\subsubsection{Overall Analysis of Gun Owners’ Responses}

Overall, when the attitudes of male and female gun owners are combined, we can see that they perceived the main causes of gun culture to be "family influences", "lack of economic opportunities", "TV and media influences", and the "ease to legally obtain a gun”. These results contradict the findings of Fox and DeLateur (2014) since those authors could find no direct link between consumption of violent media and violent behaviour. The respondents believed "NRA influence" to be the least contributing factor to gun culture which is consistent with the Gallop poll carried out in 2016 showing that 58\% of Americans had a favourable view of the NRA.

Both males and females were largely in agreement that possible solutions to America's gun issues would be to expand background checks; start a federal database; ban the sale of assault weapons; and prevent the mentally ill from purchasing a firearm. Overall, most of these opinions agree with the beliefs of the NRA; however, the NRA does not recommend the banning of sale of assault weapons. Respondents of both genders agreed with Vizzard (2015) that the mentally ill should be prevented from owning a gun. However, this result is inconsistent with Densley and Peterson (2017) who found that the mentally ill do not pose a greater threat to society than the non-mentally ill. An interesting question to ask of these respondents would have been how they feel about the fact that President Trump revoked the ban of sales to the mentally ill when he came into office.

When the respondents were asked whether they believed Congress would pass gun laws in the future they mostly answered "extremely unlikely" or "slightly unlikely" meaning that the gun owners in the study had belief in their government to protect their guns and second amendment rights; and that they did not think that there would be any significant changes to gun culture in the near future. 


\subsubsection{Analysis of Non-gun Owners’ Responses}

The non-gun owner respondents were the clear majority voice in this study with $61 \%$ of respondents falling into this category. Within this demographic, $60 \%$ were under the age of 44 and 66 were in "full time employment".

Fifty-four percent (54\%) of respondents knew someone who owned a gun despite not being an owner themselves. What is perhaps interesting to note here is that all male non-gun owners knew someone who owned a firearm. Seventeen percent (17\%) also knew someone who had been the victim of a gun crime. Three (3) respondents opted to leave further comments to explain this with 2 simply stating "police officer”. It is unknown how they knew this police officer in question. The other respondent left the following comment: "My brother has been shot twice, thankfully not fatally. Once was an accident and once was at work. He is a police officer.” We can see that this respondent also knew a police officer who had been injured; however, this was his / her brother and the victim was not fatally wounded.

We can observe the results for question 8 for non-gun owners below; this question was designed to determine what the respondents believed to be contributors to gun culture.

\section{Insert Figure 7 about here}

We can see here that the "ease to legally own a gun" is the most common selection with 63\% of respondents choosing this. We can also see the vast difference of beliefs between gun owners and non-gun owners as 31\% of respondents have chosen "NRA influence" which no gun owners chose in their top three choices. Non-gun owners viewed the NRA as having a major influence over, presumably, the gun owners, i.e. over people other than themselves. By contrast, gun owners were unwilling to admit that their “independent thinking” might have been formed by, or even influenced by, NRA discourse and practices. Also, worth noting in these results is that $26 \%$ chose "lack of economic opportunities" whereas this was the most popular choice for male gun owners. This could be explained tentatively by how the workings of capitalism and Strain Theory more severely affect the gun owning population as compared to the non-gun owners. Perhaps the non-gun owners are more financially secure and see no reason to own a firearm. "Family influences and instability" also ranked lower with non-gun owners perhaps meaning that alienation does not affect them as much and may suggest that the respondents come from more well-off neighbourhoods on average. Again, further questioning would need to be carried out to determine the reasons for the difference in answers. There could well be regional factors in play here (gun culture more widely 
acceptable in the American South, for example) and we have no information about where in the U.S.A the survey respondents hail from or are based. One area where the gun owners and non-owners agreed is that TV and media are a major influence upon gun culture with $43 \%$ of non-gun owners choosing this option. Motives might differ here between the groups with non-gun owners blaming media as a form of sociological comment; whereas gun owners choose to shift blame from gun owners, like themselves and the NRA, to media which is perceived as able to influence the young and the mentally ill more than the typical "mature" gun owner.

Where the two groups disagreed would be when asked if they believe stricter laws should be passed with 97\% of non-gun owners selecting “definitely yes” or "probably yes”. Sixty percent (60\%) also believe that guns should be "banned completely", again in contrast to the gun owners. The researchers were not surprised at all by these major differences in opinion although the figure of $60 \%$ is lower than we expected.

There were agreements and disagreements between the groups regarding the most debated issues of gun culture. We can see this in the results of question 12 .

\section{Insert Figure 8 about here}

We can see that the non-gun owners largely agreed with the gun owners in that they believe that the mentally ill should be prevented from purchasing guns; background checks should be stricter; a federal database enforced; and a ban on the sale of assault weapons implemented. However, by contrast, the non-gun owners are not in agreement about arming teachers or expanding conceal-and-carry laws. Once again this could be due to the lack of NRA influence upon this group; therefore, they are more likely to disagree with its policies.

Interestingly, only 37\% chose the option "guns should be outright banned" which contrasts with the previous question in which $60 \%$ said they believed guns should be banned. This is perhaps an oversight on behalf of the respondents, or maybe the question design was too difficult to understand, and some respondents did not know to choose every option they were in agreement with.

We can conclude that non-gun owners perceived the ease to own a gun legally; the NRA influence; and the influence of TV and media to be the main causes of gun culture. They also agreed with gun owners that possible solutions would be to restrict sales to the mentally ill; have stricter background checks; start a federal database; and ban the sale of assault weapons. They did not agree that arming teachers or expanding conceal-and-carry 
laws would be effective measures to take, showing that these people can be characterized as classic humanitarians or peaceful liberals.

When asked if they believe more laws would be passed in the future, sixty percent (60\%) believed that Congress would be either "extremely unlikely" or "moderately unlikely" to pass more gun control laws. Whereas this would be pleasing to gun owners, the fact that most non-gun owners have stated they want a complete ban of guns means this outcome would not be an attractive option to them. We may even theorize that these respondents would feel a sense of alienation from their own government and feel the strains of C. Wright Mills' Conflict Theory in which the power elite running America do not have their best interests in mind and, under capitalism, favour profits over public opinion.

\subsection{Conclusion}

The majority of the respondents (both non-gun owners and owners) believe that the ease to own a gun and the influence of TV and other media are the main contributors to gun culture. The most interesting insight gained via this question was the fact that no gun owners believed the NRA to have any influence upon the gun culture, demonstrating their power over this group of individuals. Also, male gun owners strongly believed that lack of economic opportunities were to blame for the gun culture created in America. This is in agreement with the arguments of the Theory Framework section that capitalism and Strain Theory affect males much more than they affect females due to the pressures thrust upon males by American society.

The respondents largely agreed that possible solutions would be to curb gun sales to the mentally ill, enforce background checks at gun shows, start a federal database tracking gun sales and ban the sale of assault weapons and high capacity magazines to the public. The researchers were not surprised by these findings as these are the solutions most debated after every major shooting in America. Mental health was discussed extensively within the Literature Review section and the link between this and shootings is mainly fuelled by the media with Densley and Peterson (2017) finding no direct link between mental illness and violence. Also, the banning of assault weapons is so often called for by the public after mass shootings when these types of firearms are used; however, Mayors Against Illegal Guns (2013) found that these types of weapons were only used in fifteen percent of mass shootings between January 2009 and September 2013. By applying the same logic, it can be concluded that those who agree with an assault weapons ban should be more likely to agree with a ban 
on semi-automatic handguns which Mother Jones (2016) found were much more prevalent. However, the research showed this was not the case.

What was most interesting in these findings was the fact that gun owners also called for conceal-and-carry laws to be extended and for teachers to be armed in schools and colleges, believing that these options would be a possible solution to end gun violence. Studies discussed in the Literature Review section disagree with this. For example, Swanson (2000) stated that more armed civilians may lead to more accidental gun deaths. Again, the researchers were unsurprised by this as these opinions strongly represent the opinions of the NRA and the influence of the NRA upon gun owners is evident throughout this research.

The majority of respondents agree that they do not believe any changes will occur to gun controls laws in the future and therefore the probable future of gun culture will remain largely the same as it is now. We can deduce that the non-gun owners, who mostly called for a complete ban on firearms, would not be happy with Congress not addressing this issue. We can relate this back to Conflict Theory in that the elite powerful people running America do not prioritize public interest. This was evident in the Literature Review where we saw that the NRA donated highly to Trump's presidential campaign, essentially meaning that the president will value the NRA's interest above that of the general population. The unequal social disorder between that of the bourgeoisie and the proletariat is evident. Gun owners, however, fear that Congress will begin to address these issues and perhaps pass more laws prohibiting their second amendment rights. This may lead them to distrust the government, which would agree with the study by Jiobu and Curry (2001), which found that individuals who mistrust their government are more likely to arm themselves.

\section{Conclusion}

\subsection{Introduction}

The research questions will be answered and explained, and recommendations given where appropriate.

\subsection{Recommendations}

The researchers recommend that further research be conducted in this area in order to gain a larger understanding of public opinions. Firstly, a much larger sample size would be recommended as the 57 respondents may not be representative of the whole population. Secondly, the researchers feel that further interviews would need to be carried out as this 
would allow further probing which would have been extremely useful in this study. A more thorough understanding of the respondents' backgrounds, family lives, and political views would have been beneficial in this study in order to apply theories more accurately. Also, it became evident in the analysis of findings that an extremely useful question would have been to ask respondents their race. This was considered at the start of the survey process; however, the researchers felt that this question may have been deemed too controversial by some respondents and they may not have wanted to participate further in the study due to this. Also, the survey aimed to identify attitudes and opinions which are of course subject to change at any time as the individuals who replied may change their views for various reasons.

\subsection{Research aims and findings}

The research aimed to find the attitudes and opinions of American citizens towards gun culture within their country. In particular we wanted to find out what the respondents believed to be the causes and influences upon gun culture. The research findings have been thoroughly discussed within the previous section and it can be concluded that gun culture in America does indeed affect every citizen whether they agree or disagree with their second amendment rights. However, lack of political will, inability to pass reasonable laws, a toxic violent society, and sheer proliferation ensure that the industry will always put its profit ahead of the public's safety. Until this situation changes, the cycle of gun culture violence in America will continue on unabated. 


\section{References}

Amies, N. (2008) Marx continues to influence 125 years after his death. [Online] Available: http://www.dw.com/en/marx-continues-to-influence-125-years-after-his-death/a-3190306 [Accessed: 9 February 2018]

Barnes, T. (2018) Las Vegas Shooting. The Independent. [Online] 10 February. Available: http://www.independent.co.uk/news/world/americas/las-vegas-shooting-stephen-paddockmandalay-bay-hotel-58-killed-autopsy-a8204081.html [Accessed: 24 February 2018]

Baron, S. (2006) Street youth, strain theory and crime. Journal of Criminal Justice. Vol 34 92), pp $209-223$.

Beach, J.M. (2007), The ideology of the American dream: two competing philosophies in education, 1776-2006. Educational Studies. Vol 41 (2), pp 148 - 164.

Beer, J. (2017) How NRA advertising changed the second amendment. [Online] Available: https://www.fastcompany.com/40477572/how-nra-advertising-changed-the-secondamendment-and-american-gun-culture [Accessed: 19 December 2017]

Bellesiles, M. (1996) Origins of gun culture. The Journal of American History. Vol 83 (2), pp 425-455.

Blumenfeld, W. (2016) God, guns and capitalism and the culture of firearms in the U.S. [Online] Available:

https://www.researchgate.net/publication/305000284_God_Guns_and_Capitalism_and_the_ Culture_of_Firearms_in_the_US [Accessed: 18 January 2018]

Brent, D., Miller, M., Loeber, R., Mulvey, E. and Brimaher, B. (2013) Ending the silence on gun violence. Journal of American Academy of Child and Adolescent Psychiatry. Vol 52 (4), pp $333-338$.

Cherry, K. (2017) A Likert Scale and its pros and cons. [Online] Available:

https://www.verywellmind.com/what-is-a-likert-scale-2795333 [Accessed: 10 March 2018]

Choma, R. and Kroll, A. (2016) NRA raised record amount in 2016. [Online] Available: https://www.motherjones.com/politics/2018/01/nra-donald-trump-guns-fundraising/

[Accessed: 27 January 2018]

Cornell, S. (2006) A well-regulated militia: the founding fathers and the origins of gun control in America. New York: Oxford University Press.

Crossman, A. (2017) Understanding conflict theory. [Online] Available:

https://www.thoughtco.com/conflict-theory-3026622 [Accessed: 15 January 2018]

Darnall, D. (2011) The psychosocial treatment of parental alienation. Child and Adolescent Psychiatric Clinics of North America. Vol 20 (3), pp 479 -494.

Densely, J. and Peterson, J. (2017) Gun violence in America - The Violence Project. [Online] Available: http://www.theviolenceproject.org/wp-content/uploads/2017/10/TVP-GunViolence-in-America-4.pdf [Accessed: 25 February 2018]

Ellis, B. and Hicken, M. (2014) The money powering the NRA. [Online] Available: http://money.cnn.com/news/cnnmoney-investigates/nra-funding-donors/index.html [Accessed: 25 January 2018] 
Elwell, F. (n.d.) The sociology of C. Wright Mills. [Online] Available: http://www.faculty.rsu.edu/users/f/felwell/www/Theorists/Mills/SocMills.htm [Accessed: 28 January 2018]

Ewell, F.W. (2007) Karl Marx: On Capitalism. [Online] Available: http://www.faculty.rsu.edu/users/f/felwell/www/Theorists/Essays/Marx3.htm [Accessed: 28 February 2018]

Felton, R. (2017) What General Motors did to Flint. [Online] Available: https://jalopnik.com/what-general-motors-did-to-flint-1794493131 [Accessed: 24 February 2018]

Ferrara, P. (2014) How welfare reform can end poverty in America. [Online] Available: https://www.forbes.com/sites/peterferrara/2014/08/15/how-welfare-reform-can-end-povertyin-america-and-promote-booming-economic-growth/\#918062f15326 [Accessed: 24 February 2018]

Fisher, R. (1993) Social indirect desirability questioning bias. Journal of Consumer Research. Vol 20 (2), pp 303 - 315.

Follman, M. (2012) More guns, more mass shootings. [Online] Available: https://www.motherjones.com/politics/2012/09/mass-shootings-investigation/ [Accessed: 20 January 2018]

Fox, J.A. and DeLateur, M.J. (2014) Mass shootings in America: moving beyond Newtown. Homicide Studies. Vol 18 (1), pp 125 - 145.

Fraad, H. and Wolff, R. (2017) American hyper-capitalism breeds the lonely alienated men who become mass killers. [Online] Available: https://www.salon.com/2017/11/08/americanhyper-capitalism-breeds-the-lonely-alienated-men-who-become-mass-killers_partner/ [Accessed: 20 January 2018]

Giroux, H. (2016) Gun culture and the American nightmare of violence. [Online] Available: http://www.truth-out.org/news/item/34349-gun-culture-and-the-american-nightmare-ofviolence [Accessed: 15 January 2018]

Gun Violence Archive (n.d.) [Online] Available: http://www.gunviolencearchive.org/ [Accessed: 15 January 2018]

Haag, P. (2016) The Gunning of America. New York: Basic Books.

Hill, C. (2016) 10 things the gun industry won't tell you. [Online] Available:

https://www.marketwatch.com/story/10-things-the-gun-industry-wont-tell-you-2014-03-07 [Accessed: 20 January 2018]

Hong, J.S. (2010) Revisiting the case of Kayla Rolland a decade later. Journal of Child Adolescent Trauma. Vol 3 (1), pp 58 - 72.

Jiobu, R.M. and Curry, T.J. (2001) Lack of confidence in the federal government and the ownership of firearms. Social Science Quarterly. Vol 82 (1), pp 77-88.

Kleck, G. (1996) Crime, cultural conflict and the sources of support for gun control: a multilevel application of the general social surveys. American Behavorial Scientist. Vol 39 (4), pp $387-404$. 
Langman, p. (n.d.) Influences on the ideology of Eric Harris. [Online] Available: https://schoolshooters.info/sites/default/files/harris_influences_ideology_1.2.pdf [Accessed: 28 February 2018]

Lemieux, F. (2014) Effect of gun culture and firearm laws on gun violence and mass shootings in the United States. [Online] Available: www.sascv.org/ijcjs/pdfs/Lemieuxijcjs2014vol9issue1.pdf [Accessed: 25 February 2018]

Lopez, G. (2017) Americas gun problem explained. [Online] Available: https://www.vox.com/2015/10/3/9444417/gun-violence-united-states-america [Accessed: 15 December 2017]

Maguire, R. (2017) Audit shows NRA spending surged \$100 million amidst pro Trump push. [Online] Available: https://www.opensecrets.org/news/2017/11/audit-shows-nra-spendingsurged-100-million-amidst-pro-trump-push-in-2016/ [Accessed: 25 January 2018]

Martin, C.L. (1995) Stereotypes about children with traditional and nontraditional gender roles. Sex Roles. Vol 33 (11-12), pp 727-751.

McCarthy, T. (2017) A perennial American question: why has gun control failed? The Guardian. [Online] 3 October. Available: https://www.theguardian.com/usnews/2017/oct/03/gun-control-america-failed-las-vegas [Accessed: 16 January 2018]

Mencken, C. and Froese, P. (2017) Gun culture in action. Social Problems (published online).

Miller, A.H. and Borrelli, S.A. (1991) Confidence in government during the 1980s. American Politics Quarterly. Vol 19 (2), pp 147 - 173.

Newport, F. (2016) American public opinion, terrorism and guns. [Online] Available: http://news.gallup.com/opinion/polling-matters/192695/american-public-opinion-terrorismguns.aspx [Accessed: 17 January 2018].

Nichols, C. (2017) How is a mass shooting defined? [Online] Available: http://www.politifact.com/california/article/2017/oct/04/mass-shooting-what-does-it-mean/ [Accessed: 28 February 2018]

Pavey, H. (2017) Kinder eggs go back on sale in the U.S. [Online] Available: https://www.standard.co.uk/news/world/the-us-is-finally-lifting-its-ban-on-kinder-eggsa3691696.html [Accessed: 25 February 2018]

Pill, R. (2018) President Trump writes heart-warming promise. [Online] Available: http://www.thegoldwater.com/news/17565-President-Trump-Writes-Heartwarming-Promiseto-7-Year-Old-Girl-that-He-ll-Protect-Her [Accessed: 9 February 2018]

Pinsker, J. (2017) Why investors bet on gun sales after a mass shooting. [Online] Available: https://www.theatlantic.com/business/archive/2017/10/gun-sales-mass-shooting/541809/ [Accessed: 21 January 2018]

Plummer, B. (2012) How the US gun industry became so lucrative. The Washington Post. [Online] 19 December. Available: https://www.washingtonpost.com/news/wonk/wp/2012/12/19/seven-facts-about-the-u-s-gunindustry/?utm_term=.0a0d370ed8fd [Accessed: 25 January 2018]

Qui, L. (2014) No1 cause of death in African American males is murder. [Online] Available: http://www.politifact.com/punditfact/statements/2014/aug/24/juan-williams/juan-williamsno-1-cause-death-african-americans-1/ [Accessed: 24 February 2018] 
Ramsey, J. (2017) Does America have a gun problem or a white supremacy capitalist problem? [Online] Available: https://www.counterpunch.org/2017/10/03/does-america-havea-gun-problem-or-a-white-supremacy-capitalist-empire-problem-2/ [Accessed: 25 January 2018]

Rosenblatt, R. (2000) The killing of Kayla. [Online] Available: http://content.time.com/time/magazine/article/0,9171,40342,00.html [Accessed: 12 January 2018]

Rummel, R.J. (2017) Understanding conflict and war. [Online] Available: https://www.hawaii.edu/powerkills/CIP.CHAP5.HTM [Accessed: 28 January 2018]

Seeman, M. (1959) On the meaning of alienation. American Sociological Review. Vol 24 (6), pp 783 - 791.

Simmons, G. (2006), Family Jewels: Sex Money Kiss, rev. and updated ed., Beverly Hills, CA: Simmons Books/Phoenix Press.

Swanson, J. (2008). Preventing the unpredicted: managing violence risk in mental health care. Psychiatric Services. Vol 59 (2), pp 191 - 193.

Swift, A. (2015) Despite criticism, NRA still enjoys majority support in the U.S. [Online] Available: http://news.gallup.com/poll/186284/despite-criticism-nra-enjoys-majoritysupport.aspx [Accessed: 15 March 2018]

United States Senate (n.d.) [Online] Available:

https://www.senate.gov/civics/constitution_item/constitution.htm\#amdt_2_(1791) [Accessed: 16 December 2017]

Vizzard, W. (2015) The current and future state of gun policy in the United States. The Journal of Criminal Law and Criminology. Vol 104 (4), pp 879 - 904.

West.L. (2016) The macabre truth of gun control in the US. The Guardian. [Online] 13 March. Available: https:/www.theguardian.com/commentisfree/2016/mar/13/the-macabretruth-of-gun-control-in-the-us-is-that-toddlers-kill-more-people-than-terrorists-do [Accessed: 31 December 2017]

Woods, A. (2013) The ideas of Karl Marx. [Online] Available:

https://www.marxist.com/karl-marx-130-years.htm [Accessed: 25 February 2018]

Younge, G. (2017) Why Americans won’t give up their guns. The Guardian. [Online] 6 October. Available: https://www.theguardian.com/commentisfree/2017/oct/06/americansguns-nra-las-vegas-shooting [Accessed: 16 January 2018] 
Figure 1 - American Gun Statistics

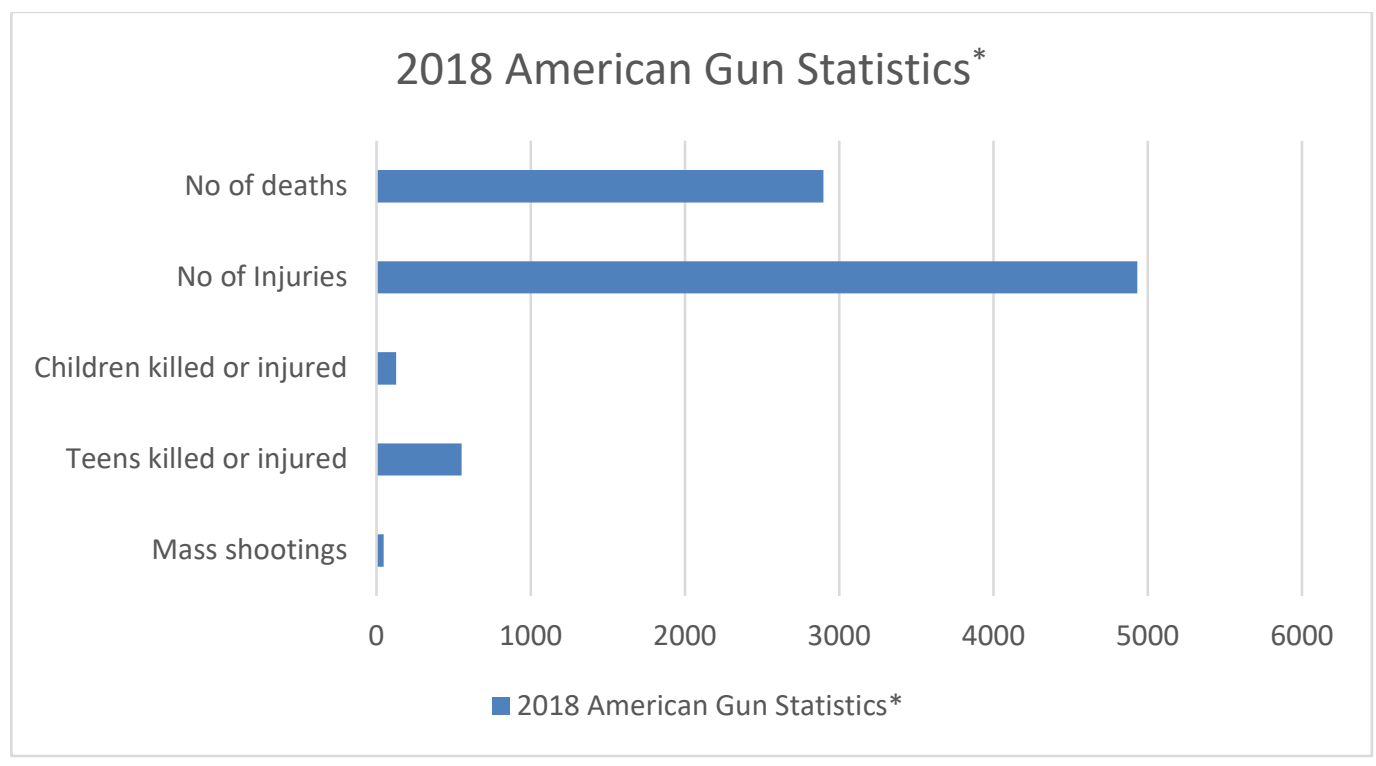

*Information correct as of 16 March 2018 Source: Gun Violence Archive 
Figure 2 - Number of Guns per 100 residents

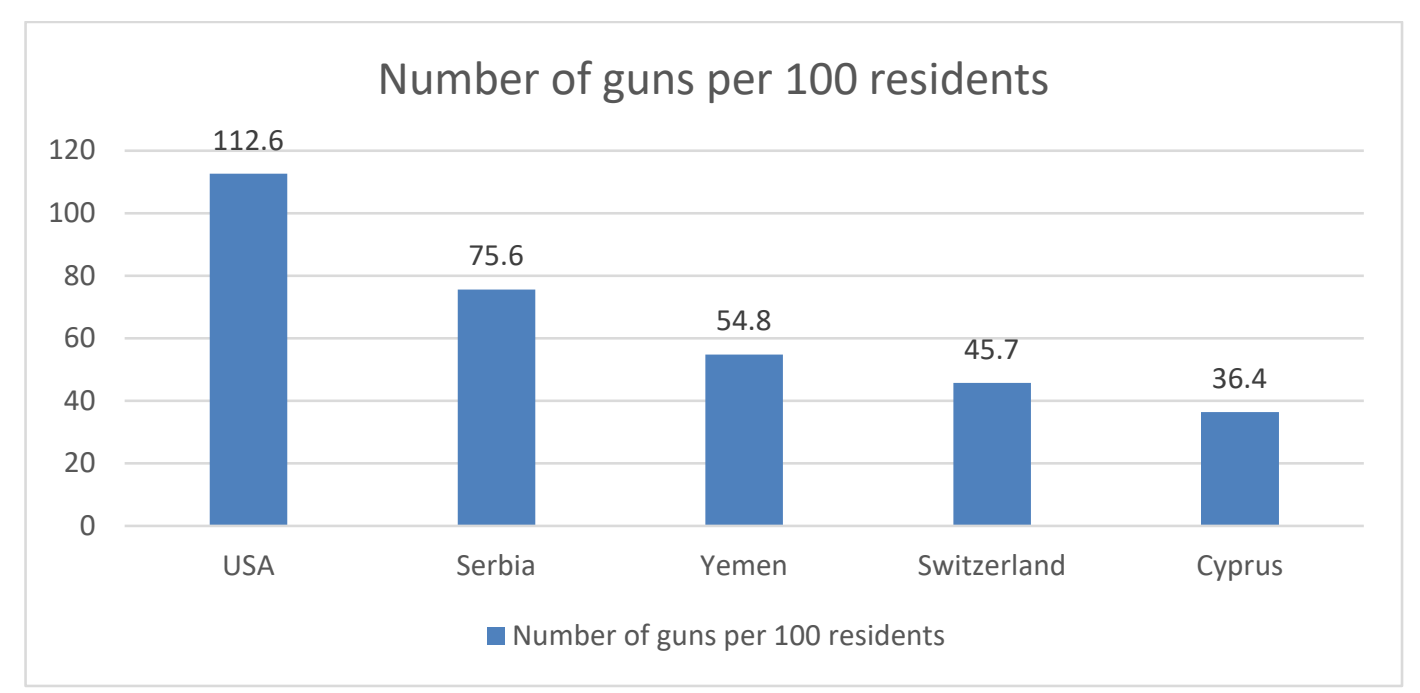

Source: Small Arms Survey 
Figure 3 - Male gun owners' reasons for ownership

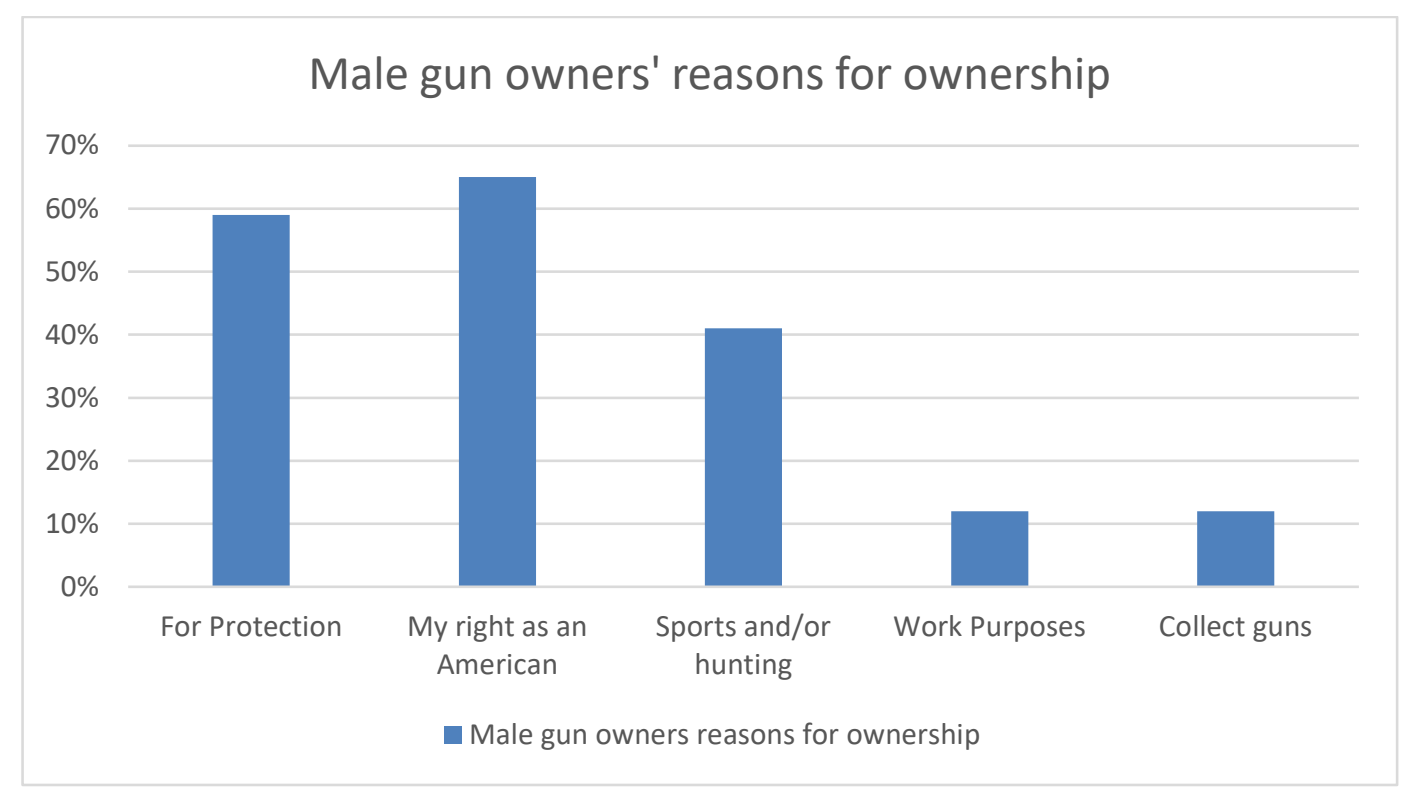


Figure 4 - Statements with which male gun owners agree

\section{Statements with which male gun owners agree}

The mentally ill should be prevented from...

Background checks at gun shows should be...

A federal database of gun sales should be kept

Assualt weapons and high capacity magazines..

Conceal and carry should be allowed in more...

Teachers should be armed

Gun laws should focus on the secondry market

Guns should be banned

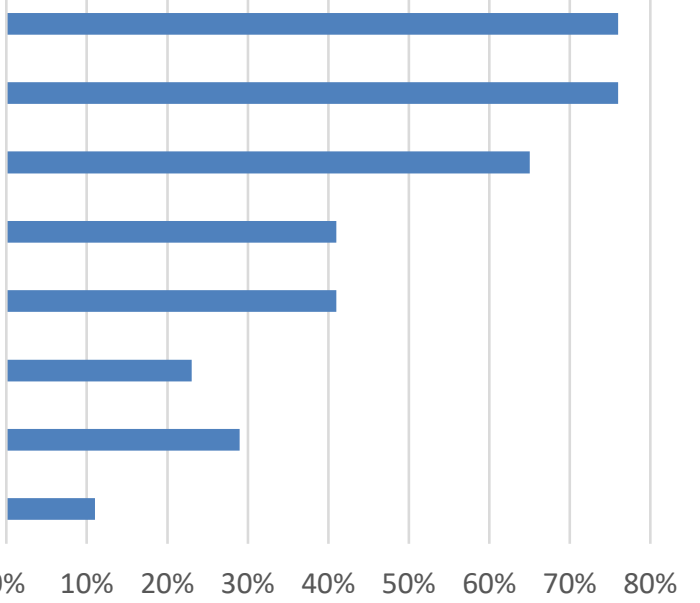


Figure 5 - Female gun owners' opinions on the influences of gun culture

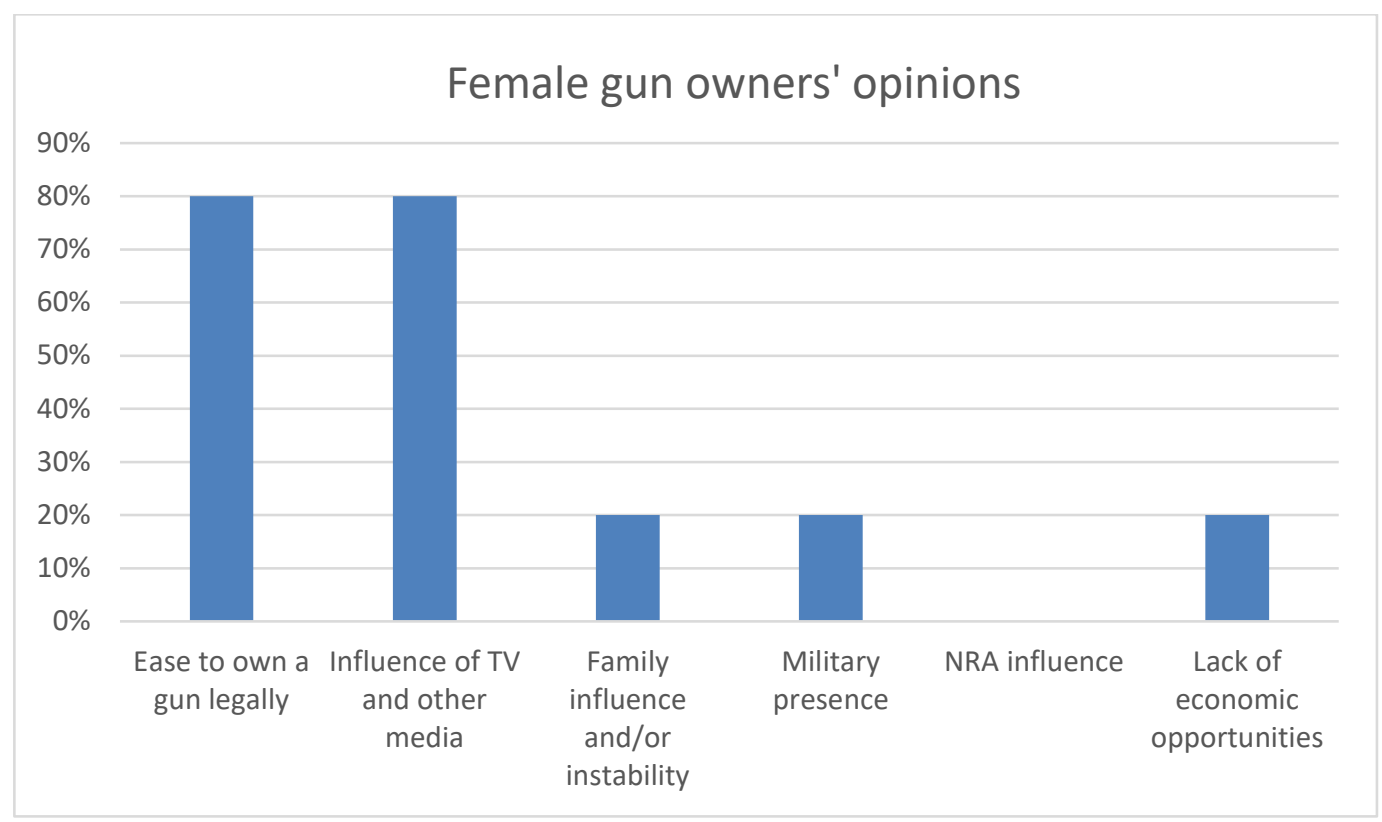


Figure 6 - Statements with which female gun owners agree

\section{Statements with which female gun owners agree}

The mentally ill should be prevented from...

Background checks should be performed at..

A federal database tracking gun sales should...

Assualt weapons and high capacity magazines..

Conceal and carry should be allowed in more...

Teachers should carry guns in schools and...

Gun control laws should focus on the...

Guns should be outright banned

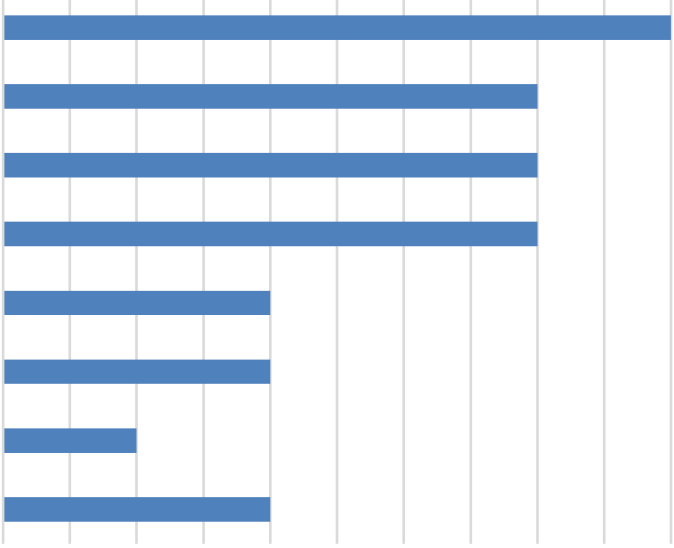

0\% $10 \%$ 20\% 30\% 40\% 50\% 60\% 70\% 80\% 90\% $100 \%$ 
Figure 7 - Non-gun owners' opinions about influences on gun culture

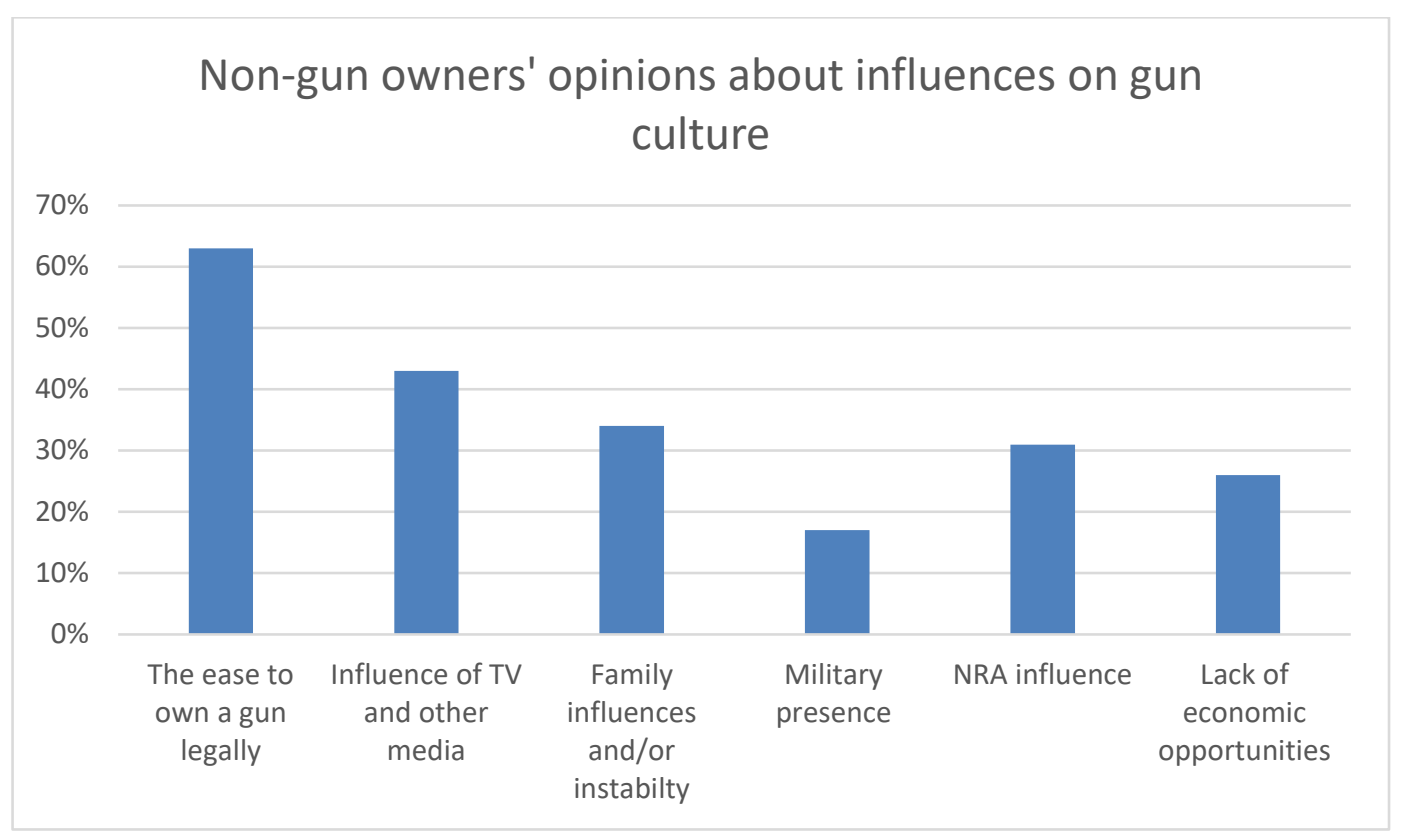


Figure 8 - Statements which non-gun owners agree with

\section{Statements with which non-gun owners agree}

The mentally ill should be prevented from...

Background checks at gun shows should be...

A federal database of gun sales should be kept

Assualt weapons and high capacity magazines.

Conceal and carry should be allowed in more.

Teachers should be armed

Gun laws should focus on the secondry market

Guns should be banned

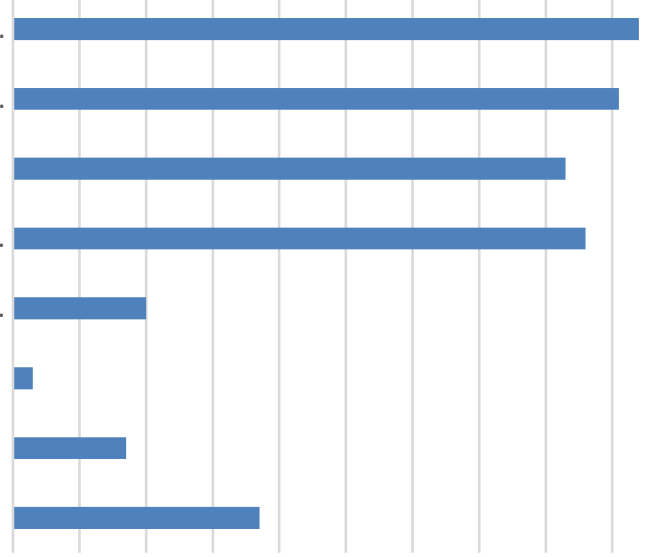

0\% $10 \%$ 20\% 30\% 40\% 50\% 60\% 70\% 80\% 90\% 100\% 